PRACE GEOGRAFICZNE

zeszyt 160, 2020, 75-94

doi: 10.4467/20833113PG.20.005.12263

Instytut Geografii i Gospodarki Przestrzennej UJ

Komisja Geograficzna, Polska Akademia Umiejętności

Wydawnictwo Uniwersytetu Jagiellońskiego

\title{
SPOŁECZNOŚĆ PLEMIENNA \\ A EKONOMICZNE KORZYŚCI Z ROZWOJU \\ TURYSTYKI - PRZYKŁAD TURYSTYKI SAFARI \\ W REGIONIE SAMBURU (KENIA)
}

\author{
Mirostaw Mika, Tomasz Kęski
}

\section{Tribal community and the economic benefits of tourism development - the case of safari tourism in the Samburu region (Kenya)}

\begin{abstract}
The article discusses the issue of economic relations between an accommodation facility providing safari tourism services and the local Samburu tribal community in northern Kenya. The study illustrates a unique case of safari tourist lodge functioning in a close relation to the traditional shepherd community in the conditions of its spatially isolated location. The local community benefits economically from permanent and occasional work for the lodge, sale of craft and agricultural products, as well as benefits, economically and socially, from the entrepreneur's charity actions and the visitors' generosity and donations. The tourist lodge operator is compelled to conduct permanent (almost every-day) trainings of employees from the local Samburu community to sustain the quality of services provided to its guests ('high-end' tourists). He also maintains close relations with the local tribal elders, among others by consulting his own intentions regarding the intensification of tourism development and his plans for establishing a local nature protection area in the form of 'conservancy'. The development of the safari facility depends strongly on local natural conditions, as well as the acceptance of its activities by members of the tribal elders, that is strictly conditioned by the entity's ability to create economic values (benefits) for the local community.
\end{abstract}

Keywords: safari lodge, tribal community, economic relations, Samburu, Kenya 
Zarys treści: Artykuł podejmuje problematykę kształtowania się relacji ekonomicznych pomiędzy obiektem noclegowym świadczącym usługi w turystyce safari a lokalną społecznością plemienną Samburu w północnej Kenii. Omówione studium przypadku ilustruje szczególną sytuację funkcjonowania obiektu turystycznego w relacji do tradycyjnej społeczności pasterskiej w warunkach semi-izolacji przestrzennej. $Z$ dysponującego ośmioma miejscami noclegowymi safari lodge społeczność miejscowa czerpie korzyści ekonomiczne w postaci pracy stałej i dorywczej oraz sprzedaży artykułów rzemieślniczych i rolniczych, a także korzyści gospodarcze i społeczne, będące rezultatem dobroczynności przedsiębiorcy i ofiarności turystów. Podmiot turystyczny, aby utrzymać jakość świadczonych usług dla gości z grupy high-end, zmuszony jest do prowadzenia stałej pracy szkoleniowej pracowników. Utrzymuje także ścisłe relacje z miejscową starszyzną plemienną, konsultując m.in. własne zamierzenia odnośnie do intensyfikacji rozwoju turystyki oraz plany powołania lokalnie przestrzennej formy ochrony przyrody w postaci conservancy. Rozwój obiektu jest silnie uzależniony od miejscowych warunków przyrodniczych, a także przyzwolenia na jego działalność ze strony członków starszyzny plemiennej, które jest uwarunkowane zdolnością tworzenia przez ten podmiot wartości (korzyści) ekonomicznych dla miejscowej społeczności.

Stowa kluczowe: safari lodge, społeczność plemienna, relacje ekonomiczne, Samburu, Kenia

\section{Problematyka badaweza}

Jednym z naczelnych postulatów zrównoważonego rozwoju turystyki jest włączanie mieszkańców obszarów recepcyjnych w łańcuch korzyści ekonomicznych, jakie implikują wydatki turystyczne (Kowalczyk 2010; Mika 2014; Niezgoda 2006). Kwestia ta od lat 90. XX w. jest szeroko omawiana w międzynarodowej literaturze naukowej. Niejednokrotnie była też przedmiotem opracowań Światowej Organizacji Turystyki, a także innych instytucji międzynarodowych i krajowych (patrz: www.e-unwto.org).

W ogólnoświatowej dyskusji nad zagadnieniem dystrybucji korzyści ekonomicznych z rozwoju turystyki wśród przedstawicieli społeczności lokalnych podejmuje się różne wątki problemowe. Główne pola dyskusji wyznaczają konteksty geograficzne, w jakich rozwój turystyki przebiega, jego formy oraz mechanizmy włączania bądź wykluczania ludności miejscowej z korzyści powodowanych przez wydatki turystyczne - realnie lub potencjalnie. Skomercjalizowanej i masowej kulturze turystycznej, będącej jednym z czynników, a także przejawów globalizacji zarzuca się skłonność do dominacji, tworzenie mechanizmów zależności i utrwalanie nierówności społecznych (Cole, Morgan 2010; Kowalczyk 2010; Mika 2014).

W przypadku krajów rozwijających się kwestia ta wyznacza szczególne pole zainteresowania przedstawicieli świata nauki, praktyków i obserwatorów życia społecznego. Za „winowajcę” nierówności społecznych, które implikuje turystyka, wskazuje się najczęściej ekspansywną i zaborczą w odniesieniu do zasobów przyrody działalność przedsiębiorstw sektora turystycznego, szczególnie podmiotów korporacyjnych o ponadnarodowym zasięgu działania (Burns, Novelli 2008; Novelli 2015). Postępujący 
w szybkim tempie proces turystyfikacji krajów tzw. trzeciego świata w drugiej połowie XX w. zaczęto określać pejoratywnie „turystycznym neokolonializmem”, jako przejaw dominacji kultury Zachodu (Kurek 2007; Nash 1989).

Z perspektywy minionych lat wiadomo już, że takie „kategoryczne” ujęcie problemu było obarczone nadmiernym uproszczeniem. Nie wdając się w rozbudowaną dyskusję, można w tym miejscu jedynie wskazać na fakt, że choć od początków intensywnej urbanizacji turystycznej krajów rozwijających się minęło już ponad pół wieku, to jednak kwestia nierówności w dystrybucji korzyści z turystyki na obszarach recepcyjnych jest nadal aktualna. Różne środowiska, także związane ze światem nauki, domagają się podejmowania konkretnych działań zaradczych w duchu tzw. demokratyzacji turystyki.

Ideowy postulat sprawiedliwości w dystrybucji korzyści podnosi się dziś do rangi imperatywu w rozwoju obszarów recepcji ruchu turystycznego. W wymiarze operacyjnym wyznacza on zasadę etyczną w biznesie turystycznym odwołującą się do jego społecznej odpowiedzialności. Myślenie w duchu sprawiedliwości dystrybutywnej implikuje jednak normatywny punkt odniesienia dla funkcjonowania sektora turystycznego, co nieuchronnie prowadzi do formułowania ocen na temat kierunków procesów rozwojowych i wyborów w sferze działalności biznesowej (Higgins-Desbiolles 2008, 2018; Pritchard i in. 2011).

Szczególne miejsce w dyskursie wokół społecznych funkcji turystyki zajmuje kwestia włączania w sferę ekonomicznych korzyści z wydatków turystycznych przedstawicieli grup etnicznych lub też szerzej - rdzennych mieszkańców (indigenous peoples) obszarów użytkowanych turystycznie (Novelli 2015). Potrzeba kształtowania „właściwych” relacji między turystyką a społecznościami etnicznymi w myśl idei zrównoważonego rozwoju została wyrażona m.in. w rekomendacjach Światowej Organizacji Turystyki skierowanych do biur podróży, przewodników turystycznych, turystów oraz przedstawicieli ludności odwiedzanej, które zostały przedstawione w opracowaniu pt. Recommendations on Sustainable Development of Indigenous Tourism (UNWTO 2019).

Z oczywistych względów nie można odmówić słuszności przesłankom, które stoją u podstaw postulatów, aby turystyka stawała się czynnikiem sprawczym wzmacniania i podtrzymywania różnorodności kulturowej obszarów recepcyjnych oraz poprawy sytuacji życiowej rdzennych mieszkańców. W tym miejscu nasuwa się jednak pytanie: czy rzeczywiście odpowiedzialność za włączanie przedstawicieli grup etnicznych w sferę korzyści z turystyki przyjazdowej leży wyłącznie po stronie sektora turystyki i czy dążenie do dystrybucyjnej sprawiedliwości w lokalnym rozwoju turystyki ma mieć tak silnie jednokierunkowy charakter? Intuicja „geograficzna” nakazuje przyjrzeć się bliżej sytuacjom, w których proces świadczenia usług dla turystów jest uwikłany w inne procesy oraz relacje społeczne i ekonomiczne na poziomie lokalnym. Szczególnie kiedy odbywa się to w warunkach kulturowych reprezentujących 
systemy wartości i organizację społeczną często daleko odmienne od zunifikowanych systemów wartości nowoczesnego, konsumpcyjnego społeczeństwa.

Możliwość bezpośredniej obserwacji wzajemnych relacji, w jakie wchodzą przedsiębiorca (podmiot) turystyczny i rdzenna ludność miejscowa w procesie budowania łańcucha wartości dla turystów, pojawiła się w trakcie dwukrotnych pobytów naukowych w północnej Kenii (wrzesień 2017 i wrzesień-październik 2018 r.), w regionie zamieszkałym przez grupę etniczną Samburu. Uwagę zwrócono wówczas na funkcjonowanie turystycznego obiektu noclegowego Desert Rose Lodge, działającego pod szyldem safari tours, specjalizującego się w obsłudze turystów zainteresowanych poznawaniem i obserwacją dzikiej fauny, naturalnych form krajobrazu oraz życia codziennego i kultury rdzennych mieszkańców. Działalność tego obiektu wybrano jako studium przypadku dla weryfikacji postawionego wyżej pytania, kierując się następującymi przesłankami.

Po pierwsze, obiekt ten jest zlokalizowany peryferyjnie w trudno dostępnym komunikacyjnie terenie górskim Mount Ng'iro i jest jedynym w tym regionie obiektem świadczącym usługi turystyczne dla klientów z grupy high-end. Podmiot zarządzający tym obiektem jest doświadczonym operatorem turystyki przyrodniczej, który przez ponad dwie dekady funkcjonowania omawianego obiektu noclegowego wypracował trwałe relacje z lokalnym środowiskiem społecznym należącym do grupy etnicznej Samburu. Po drugie, z perspektywy dotychczasowych badań nad ekonomiczną funkcją obszarów o ponadprzeciętnych i rzadkich cechach przyrodniczych wynika, że podstawę do budowania łańcucha wartości ekonomicznej w toku udostępniania obszarów dla ruchu turystycznego stanowi wykształcenie się sieci relacji funkcjonalnych pomiędzy użytkownikami tychże wartości (Mika i in. 2015). Wreszcie, wybór szczegółowego studium przypadku podyktowany był faktem, iż w dyskusji na temat implementacji zasad zrównoważonego rozwoju w turystyce wielokrotnie podkreślano wagę i skuteczność rozwiązań wdrażanych w małych projektach rozwojowych, w tym indywidualnych, wręcz jednostkowych działań podejmowanych przez aktorów rozwoju turystyki na poziomie lokalnym (Mika 2014).

\section{Cel opracowania}

Celem artykułu jest ukazanie form oraz zakresu ekonomicznego oddziaływania podmiotu turystycznego specjalizującego się w turystyce safari na społeczność rdzennych mieszkańców plemienia Samburu na przykładzie Desert Rose Lodge w północnej Kenii. 


\section{Metodyka badań i źródła informacji}

W trakcie badań terenowych przeprowadzono wizję w regionie Mount Ng'iro w celu rozpoznania warunków miejscowych, w których funkcjonuje obiekt turystyczny Desert Rose Lodge (ryc. 1). Szczególną uwagę poświecono zasobom przyrodniczym masywu Mount Ng'iro i jego otoczenia, rozpoznaniu zakresu i sposobu gospodarczego użytkowania środowiska przyrodniczego oraz sytuacji społecznej i wartościom kultury lokalnej. Odrębna sfera obserwacji obejmowała funkcjonowanie rozpatrywanego obiektu noclegowego, zakresu świadczonych w nim usług, w tym specyfiki modelu gościnności, a także powiązań Desert Rose Lodge z innymi operatorami turystyki safari w krajowym systemie recepcji.

$\mathrm{Z}$ punktu widzenia realizacji celu badań podstawową kwestią było ustalenie, w jakim stopniu badany obiekt jest zakorzeniony w lokalnym systemie społecznym, z punktu widzenia powiązań ekonomicznych i relacji - ich zakresu oraz treści, ukształtowanych w związku z prowadzoną lokalnie turystyczną działalnością biznesową. W tym celu przeprowadzono wywiady swobodne z właścicielem przedsiębiorstwa Desert Rose Ltd z siedzibą w Nairobi, dwoma pracownikami kadry zarządzającej obiektem, a także przedstawicielami społeczności lokalnych, w tym z członkiem starszyzny plemiennej wsi WasuRongai leżącej w sąsiedztwie obiektu turystycznego oraz 5 mieszkańcami tej wsi, którzy równocześnie byli pracownikami Desert Rose Lodge. W trakcie wywiadów z członkami społeczności Samburu korzystano z pomocy miejscowego tłumacza.

\section{Informacje podstawowe}

Obiekt noclegowy Desert Rose Lodge jest położony w północnej Kenii w odległości drogowej około 700 km od Nairobi. Desert Rose Lodge specjalizuje się w obsłudze turystów z elitarnej grupy high-end, eksplorujących atrakcyjne przyrodniczo i kulturowo tereny północnej Kenii, w tym m.in. okolice Jeziora Turkana, dolinę Suguty, pustynię Chalbi. W łańcuch wartości dostarczanych gościom włącza się bezpośrednie spotkanie z dziedzictwem kulturowym i życiem codziennym rdzennych ludów Samburu, Turkana i Rendile.

Ze względu na peryferyjną lokalizację obiekt jest trudno dostępny transportem drogowym. Czas przejazdu samochodem terenowym ze stolicy wynosi około 12-13 godzin. Znaczny odsetek gości dociera jednak do Desert Rose Lodge drogą powietrzną, obiekt dysponuje bowiem lądowiskiem dla helikopterów i awionetek. Na miejscu do dyspozycji turystów jest 8 miejsc noclegowych w czterech wysokiej klasy obiektach typu open space safari lodge. Gościom świadczy się ponadto pełne wyżywienie w systemie restauracyjnym, usługi transportowe, przewodnickie 


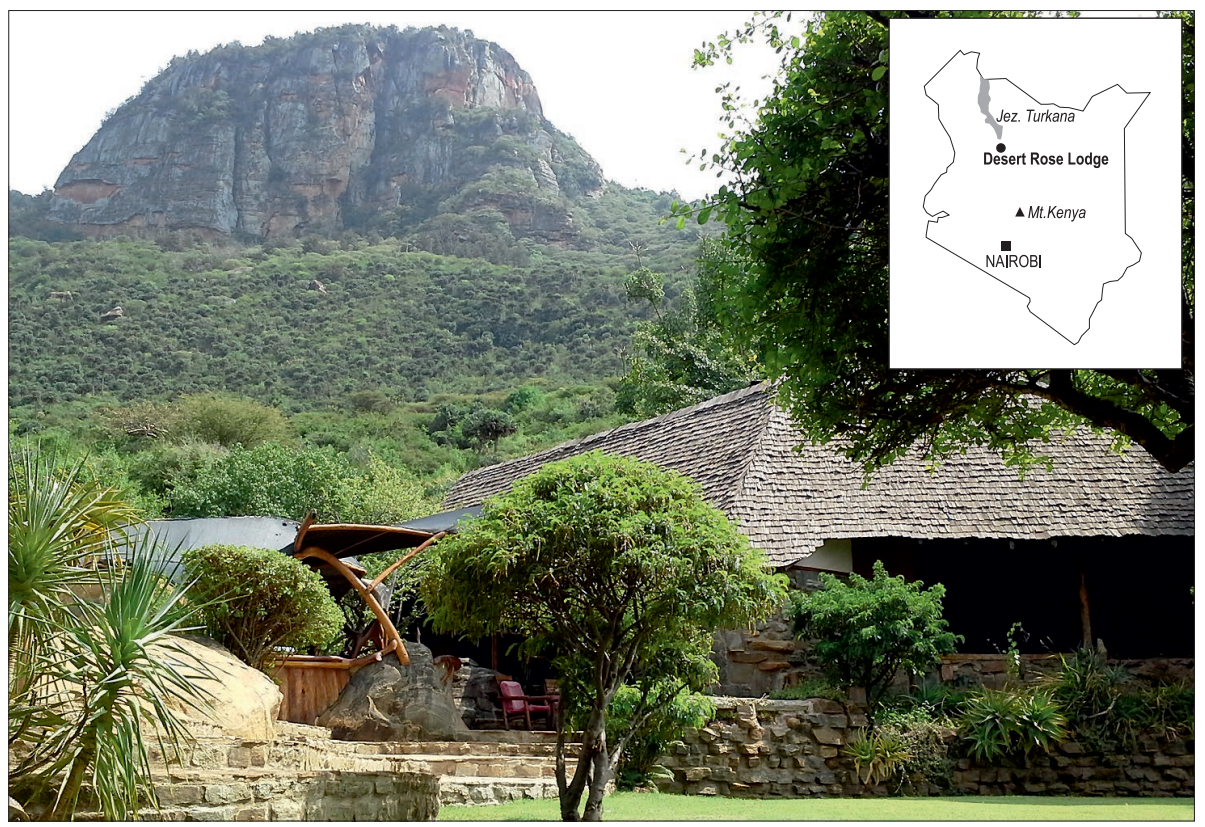

Ryc. 1. Lokalizacja obiektu noclegowego Desert Rose Lodge

Fig. 1. Location of the Desert Rose Lodge

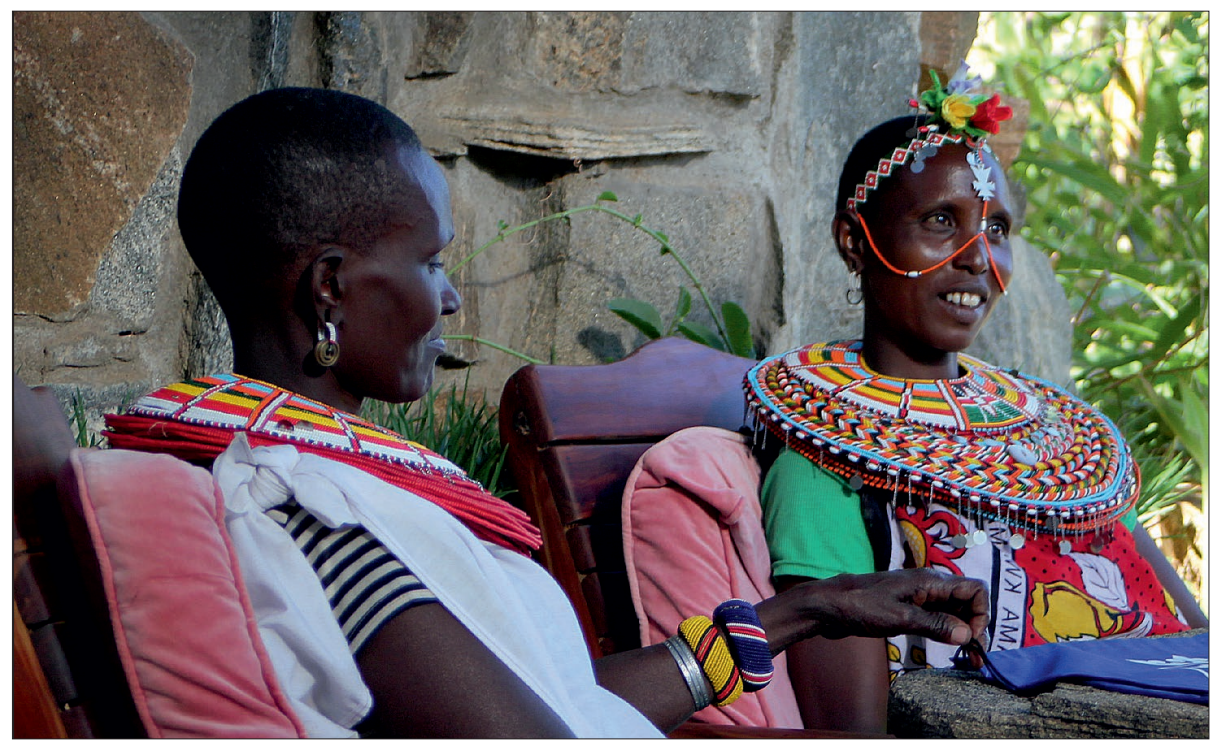

Ryc. 2. Pracownice Desert Rose Lodge z miejscowej społeczności Samburu

Fig. 2. Employees at the Desert Rose Lodge from the local Samburu community 
i kulturalne. Informacje na portalu rezerwacyjnym Booking.com wskazują, że cena pobytu all inclusive dla dwóch osób na dobę wynosi 4100 zł. Średnio pobyt gości w Desert Rose Lodge mieści się w przedziale 2-3 noce.

Produkt turystyczny Desert Rose Lodge jest etykietowany jako „ekologiczny”, do czego wprost odwołuje się jego promocja na rynku. Gospodarcze funkcjonowanie obiektu opiera się na minimalizacji jego wpływu na środowisko przyrodnicze. Woda jest pozyskiwana i transportowana systemem rurociągowym ze źródła zlokalizowanego około 800 m od obiektu. Odpady są segregowane i wywożone, a ścieki gromadzone i oczyszczane na miejscu. Większość elementów konstrukcyjnych i dekoracyjnych w budynkach lodge pochodzi z materiałów pozyskanych na miejscu„z przyrody”, jak: kamień budowlany, piasek, powalone konary drzew.

Jednym z najpoważniejszych wyzwań organizacyjnych jest zaopatrzenie obiektu w produkty spożywcze i użytkowe. Większość tego typu produktów, łącznie z paliwem do generatora i lamp naftowych, dowozi się z Nairobi lub z miejscowości położonych w regionie masywu Mount Kenii (około 400 km). Średnio miesięczne koszty utrzymania Desert Rose Lodge wynoszą około 6000 USD wraz z pensjami jej pracowników. Aby pokryć te koszty, niezbędne jest zapewnienie obłożenia obiektu w ciągu roku na poziomie co najmniej $10 \%$.

\section{Społeczność lokalna}

Desert Rose Lodge jest położony w hrabstwie Samburu zamieszkałym w zdecydowanej większości przez liczące nieco ponad 300 tys. członków plemię Samburu. Pod względem etnicznym i kulturowym Samburu są bliscy Masajom i są zaliczani do grupy etnicznej Nilotów Wschodnich. Posługują się językiem Maa w dialekcie samburskim (Północny Maa) (Ole Sena, Ssennyonga 1986; Sommer, Vossen 1993). Samburu są plemieniem pasterskim prowadzącym semi-nomadyczny tryb życia na sawannowych i półpustynnych terenach północnej Kenii. Ich życie codzienne determinuje wypas zwierząt odpornych na długotrwałe susze, jak: kozy, owce, osły, wielbłądy (Kahindi 2001). Samburu jako lud pasterski cechuje względnie niski poziom kultury uprawy roli.

Podstawę władzy społeczności Samburu stanowią mężczyźni, którzy w młodości zostali obrzezani. Grupa mężczyzn jest zorganizowana według systemu wiekowego ${ }^{1}$.

\footnotetext{
${ }^{1}$ System wiekowy Samburu dzieli się na: dzieciństwo (chłopięctwo) -> obrzezanie $\rightarrow>$ okres wojowniczy -> starość (przynależenie do starszyzny). System ten organizuje społeczność Samburu według ról i zasad podobnych do grup polityczno-wojskowych. Ma też kluczowe znaczenie z punktu widzenia współpracy i ustalania nowych sekcji terytorialnych plemienia (Simonse, Kurimoto 1998).
} 
Władzę plemienną sprawuje starszyzna² (gerontokratyczny system władzy). Siła starszyzny powiązana jest z wiarą w domniemane przekleństwa, którymi starszyzna może obarczyć swoich podwładnych. Starszyzna ma także „monopol” na aranżowanie małżeństw ${ }^{3}$ wewnątrz plemienia (Spencer 2004).

Społeczności żyjące w otoczeniu lodge, należące do wiosek WasuRongai i Somale, liczące łącznie około 3 tys. mieszkańców, żyją w znacznym rozproszeniu oraz w odizolowaniu od regionalnych ośrodków gospodarczych i administracyjnych. Zachowały tradycyjny styl życia w silnym powiązaniu z przyrodą. Ludność ta jest na ogół słabo wykształcona. Podstawą jej wyżywienia i utrzymania są produkty pochodzące z działalności pasterskiej (mleko, krew, mięso) oraz zbieractwa (miód, zioła, drewno).

\section{Desert Rose Lodge jako podmiot aktywizacji lokalnej społeczności}

\section{Zatrudnienie}

W omawianym obiekcie noclegowym znajduje stałą pracę 18 osób z lokalnej społeczności Samburu. Grupę tworzy 14 mężczyzn i 4 kobiety, w przedziale wiekowym między 20 a 60 lat. Poziom wykształcenia tych osób jest niski. Wszyscy są mieszkańcami pobliskiej wioski WasuRongai.

Pracownicy obiektu są przyporządkowani do trzech kategorii zatrudnienia. Pierwszą grupę (5 osób) tworzą osoby pracujące przy bezpośredniej obsłudze gości, w tym 2 osoby na stanowisku kelnera (jedna posługuje się językiem angielskim) oraz 3 (kobiety) obsługujące pokoje w lodge. Druga grupa (2 osoby) to pracujący w kuchni, z czego jedna osoba na stanowisku pomocnika kucharza, a druga jest odpowiedzialna za przygotowywanie posiłków dla pracowników. Najliczniejszą grupę stanowią pracownicy obsługi technicznej, w tym 4 osoby są stale zatrudnione do prac związanych z utrzymywaniem drogi dojazdowej (intensywnie erodowana w wyniku opadów i na skutek przepędzenia bydła) oraz lądowiska, 6 osób do pracy w warsztacie naprawczym oraz przy innych pracach związanych z utrzymaniem

\footnotetext{
${ }^{2}$ We władaniu społecznością przez starszyznę stosowane są dwie strategie - dyskusji oraz przekleństw. Zazwyczaj małe problemy i tematy bieżące omawiane są przez niewielką grupę starszych, natomiast poważne problemy lub konflikty omawiane są w serii spotkań, tzw. zebrań starszyzny (Kahindi 2001). ${ }_{3}^{3}$ Żony dobierane są przez starszyznę dla młodszego mężczyzny zgodnie z etapem systemu wiekowego. Od momentu zawarcia małżeństwa żony powiązane są z najbliższym otoczeniem (klanem) męża i mogą nadal utrzymywać kontakty z własnym klanem. Każdy mężczyzna Samburu aspiruje do posiadania więcej niż jednej żony. Małżeństwa Samburu mają charakter egzogamiczny. Życie małżeństwa opiera się o patrylokalność, tzn. że nowo powstała rodzina zamieszkuje wioskę z rodziną męża. Obowiązuje patrylinearny system pokrewieństwa (Kahindi 2001).
} 
i konserwacją drewnianych budynków lodge (bieżące naprawy, obróbka drewna), a także do wykonywania i reperacji drewnianych mebli. Do tej grupy włącza się także stałego ogrodnika odpowiedzialnego za utrzymanie roślin w przestrzeni dla gości i otoczeniu budynków.

W relacji między kadrą zarządzającą a pracownikami pośredniczy przedstawiciel tej grupy, którą jest osoba o uznanej pozycji w lokalnej społeczności plemiennej. W tym przypadku jest to wojownik-tropiciel, który oprócz wykonywania własnych zadań pracowniczych, pełni rolę nieformalnego przełożonego (supervisor) nadzorującego pracę pozostałych członków Samburu. Uczestniczy także regularnie w spotkaniach kadry zarządzającej i w planowaniu zadań organizacyjnych.

W grupie pracowniczej kobiety stanowią mniejszość, co wprost wynika z uwarunkowań kulturowych (ryc. 2). W silnie patriarchalnej społeczności etnicznej Samburu, mężczyźni zazwyczaj nie zezwalają kobietom pracować przy obsłudze turystów, mimo atrakcyjnych warunków finansowych oferowanych w Desert Rose Lodge. Fakt, iż w obiekcie pracują cztery kobiety, w tym jedna jako kelnerka, należy uznać za przełamanie zwyczajowej sankcji społecznej.

Miesięczna pensja pracowników zgronaSamburu mieści sięw przedziale 100-150USD. Wszystkie te osoby są także beneficjentami napiwków od gości, co średnio podnosi ich miesięczny zarobek o około 50\%. Pracodawca dodatkowo wypłaca pracownikom premie. Tak więc, realne miesięczne dochody pracowników pochodzących z lokalnej społeczności wynoszą około 200-250 USD. Pracownicy mają też zagwarantowane wyżywienie w miejscu pracy. Ponadto wszyscy są przez pracodawcę objęci ochroną w postaci ubezpieczenia zdrowotnego, co należy podkreślić z uwagi na fakt, że nie jest to praktyka powszechnie stosowana w Kenii.

Obiekt noclegowy utrzymuje także stałe relacje zaopatrzeniowe z osobą prowadzącą na obrzeżach pobliskiej wsi ogród warzyw i ziół. Miesięczna wartość zakupów tych produktów spożywczych wynosi około 150 USD.

Odrębną grupę pracowniczą w Desert Rose Lodge stanowią osoby z przygotowaniem zawodowym. Zalicza się do niej: menedżera obiektu, kucharza, kierowcę safari oraz stolarza. Osoby te pochodzą spoza lokalnej społeczności i są członkami innego plemienia - Kikuyu. Praca tych osób ma kluczowe znaczenie z punktu widzenia funkcjonowania lodge oraz jakości świadczonych gościom usług. Ich miesięczne zarobki mieszczą się w przedziale 500-800 USD.

\section{Sprzedaż rękodzieła}

Wszystkie osoby odpowiedzialne za bezpośrednią obsługę gości i pokoi pracują w tradycyjnych strojach ludowych, promując w ten sposób wśród gości kulturę Samburu. W tym miejscu należy dodać, że - w świetle wypowiedzi kadry zarządzającejwprowadzenie takiego rozwiązania przyczyniło się z jednej strony do podniesienia 
atrakcyjności modelu gościnności samego obiektu, a z drugiej - istotnie zwiększyło wśród gości zainteresowanie zakupem lokalnych produktów kulturowych (rzemieślniczych), a także przyczyniło się do liczniejszych odwiedzin turystów w lokalnych siedliskach i wsiach.

Goście Desert Rose Lodge mają możliwość zakupu na miejscu produktów rzemieślniczych, pamiątek, przedmiotów codziennego użytku. W przestrzeni, gdzie przebywają turyści, zorganizowano ekspozycję takich produktów. Przedmioty są też wykonywane na indywidualne zamówienie gości. W skali roku łączna wartość sprzedaży takich produktów mieści się w przedziale 3000-5000 USD. Pozyskane tą drogą środki finansowe trafiają bezpośrednio do lokalnych wytwórców (mieszkańców), bez pośrednictwa kasy obiektu.

\section{Praca doryweza}

Źródłem dodatkowych przychodów mieszkańców są także prezentacje tradycyjnych samburskich tańców i śpiewów, organizowane dla każdej z nowo przybyłych do lodge grup turystycznych. W takich inscenizacjach bierze udział około 10-12 mężczyzn i kobiet. Za około 20-minutowy występ grupy otrzymują jednorazowo wynagrodzenie w wysokości 50-100 USD.

Ponadto istnieje zapotrzebowanie na pracę przy ochronie mienia w Desert Rose Lodge. Zajęciem tym w nocy zajmuje się dwóch wojowników-tropicieli z grupy pracowników obsługi technicznej obiektu. Dorywczą pracę na rzecz obiektu wykonuje także grupa 2-3 miejscowych mężczyzn w celu ochrony pasa startowego oraz zaparkowanych awionetek w czasie pobytu gości.

\section{Inne formy ekonomicznego wsparcia lokalnej społeczności}

Oprócz wartości ekonomicznych płynących z pracy w Desert Rose Lodge oraz sprzedaży wyrobów rzemieślniczych przedstawiciele lokalnej społeczności korzystają także z innych form wsparcia finansowego i rzeczowego, które mają związek z rozwojem turystyki przyjazdowej.

Do takich form można zaliczyć rodzaj nieformalnej opłaty miejscowej, którą Desert Rose Lodge przekazuje na rzecz lokalnej społeczności za pośrednictwem przedstawicieli starszyzny plemiennej. W toku budowania „dobrych” relacji pomiędzy właścicielem Desert Rose Lodge a miejscową ludnością ustalono, że przedsiębiorca będzie przekazywał starszyźnie kwotę 20 USD za osobonocleg każdego gościa przebywającego w obiekcie. W skali roku donacja dla mieszkańców WasuRongai z tego tytułu może osiągać wartość 10000 USD. W umowie zdecydowano, że środki te będą przeznaczone na cele edukacyjne, w tym na dofinansowania dzieci uczących się w miejscowej szkole. 
Zaangażowanie Desert Rose Lodge w sprawy lokalne znalazło także wyraz w projektach zrealizowanych na rzecz wsparcia rozwoju społeczności Samburu, a które zostały w pełni sfinansowane przez korzystających z obiektu turystów (gości). Wśród takich przedsięwzięć znalazły się m.in.: wyposażenie domostw mieszkańców pobliskiej wioski WasuRongai w 400 lamp fotowoltaicznych, budowa kilkukilometrowego rurociągu, który zaopatruje lokalną szkołę w czystą źródlaną wodę, wyposażenie szkoły w materiały edukacyjne oraz urządzenia multimedialne (łącze satelitarne, sprzęt audiowizualny) z dostępem do użytkowania dla pozostałych mieszkańców, uporządkowanie przestrzeni wsi oraz zorganizowanie systemu zbiórki i utylizacji plastikowych odpadów, a także ufundowanie dwóch stypendiów studenckich oraz doposażenie w meble szkoły w wiosce Somale. Wartość ekonomiczna zrealizowanych w minionych kilku latach takich projektów na rzecz okolicznych społeczności wyniosła w przybliżeniu 15000 USD.

\section{Efekty ekonomiczne a problemy zarządzania personelem}

Zdaniem kadry zarządzającej, podstawowym narzędziem stosowanym w procesie doboru pracowników z lokalnej społeczności Samburu jest pogłębiony wywiad rozpoznawczy, który przeprowadza się z rekrutowaną osobą. Procedura ta warunkuje zdolność budowania zespołu, późniejszy podział obowiązków oraz ich wykonanie. Oczywiście nie sam fakt wywiadu jest tu istotny (ogólnie przyjęta praktyka w przedsiębiorstwach), lecz jego treść oraz cele, na co wskazuje jedna z wypowiedzi przedsiębiorcy: ...tworzqc zespót Samburu w Desert Rose Lodge, najważniejsza jest rozmowa, by przekonać się, jak głęboko „tradycja” jest sakorzeniona w świadomości pracowników - tradycja determinujaca rygorystyczne podziaty obowiqzków, odpowiedzialności pomiędzy ptciami oraz grupami wiekowymi. Dla wielu członków społeczności Samburu określone formy zachowań oraz relacje właściwe dla obszaru kulturowego nowoczesnego świata są nie do zaakceptowania. Stąd też kluczowe w takim wywiadzie jest przekonanie się pracodawcy, czy - przykładowo - mężczyzna mający w lokalnej kulturze prestiżowy status wojownika jest skłonny wykonać prace tradycyjnie przyporządkowane kobietom, takie jak zmywanie naczyń, pomoc w kuchni bądź sprzątanie pokoi.

W ocenie potencjalnych pracowników uwzględnia się:

- ich otwartość na przełamywanie tradycyjnych podziałów i społecznych sankcji, które muszą się dokonać w procesie dostarczania łańcucha wartości turystom;

- ich wiedzę oraz zrozumienie specyfiki działalności komercyjnej;

- rozumienie łańcucha przyczynowo-skutkowego: praca $\rightarrow$ zadowolenie klienta $\rightarrow>$ wynagrodzenie $\rightarrow$ podnoszenie własnych kwalifikacji i jakości własnej pracy $\rightarrow>$ utrzymanie miejsca pracy. 
- kultywowanie wartości własnej kultury przejawiających się w noszeniu na co dzień tradycyjnego stroju, znajomości obrzędów, wierzeń, podań i opowieści, a także wola i otwartość w prezentowaniu tych wartości turystom (tańce, śpiewy); w przypadku mężczyzn (wojowników) ważne są ich umiejętności przewodnickie, znajomość zachowań i życia dzikiej fauny, umiejętność poruszania się i przeżycia w dziczy (turystyka safari);

- otwartość na zmiany, w tym chęć uczenia się, rozwoju i podnoszenia poziomu własnego życia,

- takie cechy indywidualne jak: rzetelność w pracy, lojalność, zaangażowanie, które w pełni ujawniają się dopiero po czasie.

Dla ilustracji powyższych ustaleń można przytoczyć wypowiedzi członków kadry zarządzającej:

Dobralismy kelnerów w sposób biorqcy pod uwag̨ wszystkie wa:ne dla nas aspekty. Jest więc mę̇czyzna snajqcy angielski, z ukończonq szkotq średniq, co powwala na werbalny kontakt z klientami, zrozumienie wszystkich zamówien, potrzeb, polecen managerów. Jednocześnie rozumie on potrzebe promowania kultury i tradycji plemienia Samburu, w zwiqzku z tym ubrany jest w tradycyjny samburski strój ${ }^{4}$. Druga osoba to typowe „praetamanie” tabu. Kobieta bez znajomości jezyka angielskiego, niezwykle tradycyjna w sposób naturalny. Spetnia wszystkie kryteria opisane wyzej, a więc chce się uczyć, rowwijać, jest otwarta, śmieje sie, komunikuje się z gośćmi pomimo nieznajomości języka. Jej cechy osobowości spetniajq wszystkie nasze (managementu) potrzeby. Tempo, z jakim nauczyta sie wszystkich obowiqzkow kelnera - co nie jest takie tatwe - tacznie z uktadaniem sztućcow do pięiu dań, formuty obstugiwania itp. sprawito, ¿̇e wardzo krótkim czasie stata sie ozdobq lodge, jej bardzo silnym elementem, goście jq uwielbiajq, robiq sobie z niq adjęcia i daja wysokie napiwki.

\footnotetext{
${ }^{4}$ Tradycyjny strój Samburu charakteryzuje u mężczyzn kolorowy (często różowy) materiał owinięty wokół talii w sposób podobny do szkockiego kiltu. Mężczyźni ozdabiają się naszyjnikami, bransoletkami i obrączkami, podobnie jak inne sub-plemiona Masajów. Członkowie klasy „morani” (młodzi wojownicy) zazwyczaj noszą długie warkocze, które ścinają dopiero po wejściu w kolejny etap wiekowy. Często warkocze zabarwiane są na czerwono przy użyciu ochry. Poza włosami morani zdobią ochrą nierzadko także swoje ciało. Kobiety tradycyjnie noszą dwa kawałki materiału, zazwyczaj w kolorze niebieskim i fioletowym. Jeden owinięty jest wokół talii, drugi zaś wokół piersi. Kobiety według tradycji golą włosy na głowie. Noszą więcej naszyjników i bransoletek od mężczyzn. Współcześnie na co dzień mężczyźni Samburu rzadko ubierają się w tradycyjny strój. Noszą zieloną lub czerwoną kraciastą tkaninę zwaną „kikoi” oplecioną wokół talii. Zakładają także kraciaste koszule w stylu europejskim lub jednolite podkoszulki o jaskrawych odcieniach zieleni i czerwieni. Tradycyjny ubiór jest wciąż obowiązujący przy okazji celebracji różnych świąt i ważnych wydarzeń plemiennych. Wśród kobiet nadal obowiązuje ubiór złożony z dwóch kawałków niebieskiego i fioletowego materiału. Wraz z rozwojem lokalnych sklepów $\mathrm{z}$ tkaninami w ubiorze kobiet pojawiły się motywy kwiatowe lub zwierzęce (Straight 2005).
} 


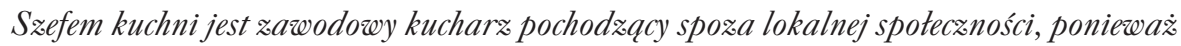
musi być doskonale wyuczony w swoim sawodzie. Jego pomocnik to mtody mę̇ंczyzna Samburu - wojownik wykonujqcy prace wwyczajowo prwyporsqdkowane kobietom-przetamanie zwyczajowego „tabu”, które nam się udato.

Zwracamy dǘq uwag̨ na otwartość pracowników w kontakcie z innymi, czy dana osoba wwyczajnie jest rozmowna, nie wstydzi się wtasnej ekspresji, wtasnej wypowiedzi, potrafi sie uśmiechać przy klientach. Wśród pracowników pochodzacych z lokalnej spoteczności obserwujemy czesto zawstydzenie w kontaktach z gośmi. Wynika ono z niezrozumienia potrzeb naszych gości, ich zwyczajów $i$ odmiennego postrzegania rzeczywistości.

Tradycyjny wygląd pracowników Samburu, brak snajomości jęska angielskiego cæy suahili stanowi atrakcje „samq w sobie” dla gości z zachodniego obszaru kulturowego. Obserwujemy też, ¿̇e im „tadniej”, tzn. bardziej tradycyjnie ubiera się dany pracownik, tym lepiej jest odbierany przez naszych gości.

Mężczyźni Samburu chętnie wykonują prace fizyczne - naprawianie, tworzenie drewnianych elementów lodge. Szybko i chętnie się uczą. Wykonują bieżące prace remontowe i budowlane.

Obserwujemy, 亡̇e w toku sajęć sawodowych sanikaja podziaty plemienne, które sq silnie

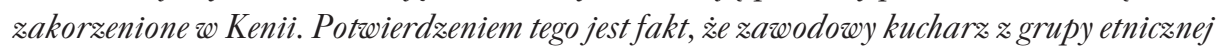
Kikuyu - najlepiej „prosperujacej” w Kenii, „decydowat się osiq̨í na state w tym tak odlegtym miejscu i odrębnej dla siebie kulturze. Zostat pr:yjęty do lokalnej spoteczności bez przeszkód i warunków. Obecnie ma już tu rodzine z samburska żonq.

Z punktu widzenia pracodawcy do podstawowych wyzwań zarządzania miejscowym personelem należy konieczność stałego nadzorowania ich pracy. Bez stałej kontroli efektywność pracy jest dość niska. Osoby te muszą podlegać też nieustannemu - „dzień po dniu” - procesowi szkolenia. Świadczenie usług dla wymagających i elitarnych gości wymaga dbałości o szczegóły. W tradycyjnym, pasterskim i na wpół-nomadycznym stylu życia Samburu nie wykształca się wrażliwości na te kwestie: ...musimy ksztattować w pracownikach dbatość o detale, które w codziennym s.yciu Samburu w zasadzie nie istnieja, np. równo potożone dywany czy prosto wiszace obrazy.

Stałym elementem w organizacji pracy w Desert Rose Lodge są spotkania kadry zarządzającej z pracownikami. Organizuje się je niemal codzienne. W ich trakcie omawia się zadania każdego pracownika, przypomina o konieczności jej wykonania z najwyższą starannością. Praca nad zespołem pracowników Samburu skupia się głównie na: 
- kształtowaniu w tych osobach chęci uczenia się oraz woli i odwagi do takich zmian zachowań, które są niezbędne do ich przystosowania się do zasad i warunków oferowanej im pracy, a które są lub mogą być w sprzeczności z ich tradycyjnym stylem życia;

- nieustannym podkreślaniu odpowiedzialności za powierzone im prace i zadania;

- uświadamianiu odmienności zasad panujących w kulturze turystycznej, akceptacji zachowań, potrzeb i wymagań gości z innych kultur, a także uczenia ich takiego postępowania, które sprosta wymaganiom i potrzebom klientów;

- kształtowaniu umiejętności planowania pracy (...czyszczenie wody w basenie dzień przed przyjazdem gości, a nie w momencie ich przyjazdu...);

- uświadamianiu mężczyznom roli kobiet w obsłudze turystycznej, co idzie w parze z koniecznością podniesienia pozycji kobiet w grupie pracowniczej;

- wprowadzaniu w relacjach pracowniczych zasad demokratycznego życia, które są niezbędne m.in. w toku dyskusji i dążeniu do porozumień: ... staramy się uświadamiać, ̇̇e starszyæna jest oczywiście ważna, ale w pracy można dyskutować ze wszystkimi i proponować zmiany, które często - szczególnie młodzi wojownicy proponuja, widzqc potraebe zmian.

Z własnych obserwacji, wypowiedzi kadry zarządzającej, a także z rozmów z pracownikami lodge wynika, że te właśnie spotkania stanowią kluczowy element w organizacji pracy i osiąganiu jej oczekiwanego poziomu. Pracownicy przechodzą bowiem z kultury ich codzienności do „świata” pracy, w którym obowiązują daleko odmienne wartości, zasady i oczekiwania. Wyzwaniem dla kadry zarządzającej jest wprowadzenie tych osób na ścieżkę wartości i sposobu myślenia według zasad obowiązujących w komercyjnej kulturze turystycznej.

Stała praca szkoleniowa - co istotne - w sposobie organizacji oraz formie dostosowana do tradycyjnych przyzwyczajeń miejscowej ludności (np. rozmowy w kręgu i w otoczeniu natury, spokojny rytm spotkania, stonowany głos prelegenta, treści przekazywane w sposób prosty i jasny, pozbawiony dwuznaczności, zachowanie hierarchii społecznej w dyskusji) przynosi - zdaniem przedsiębiorcy - oczekiwane rezultaty. $Z$ naturalnych względów w procesie tym dochodzi do stopniowego przewartościowania opinii i postaw lokalnych pracowników. Zmiany, jakie zachodzą w świadomości pracowników, mogą być jednak postrzegane negatywnie przez członków starszyzny plemiennej, która w tej społeczności pełni tradycyjnie rolę warstwy (grupy) dominującej i decyzyjnej. Dlatego też podtrzymywanie przyjaznych stosunków ze starszyzną stanowi odrębny strategiczny obszar funkcjonowania Desert Rose Lodge (ryc. 3). 


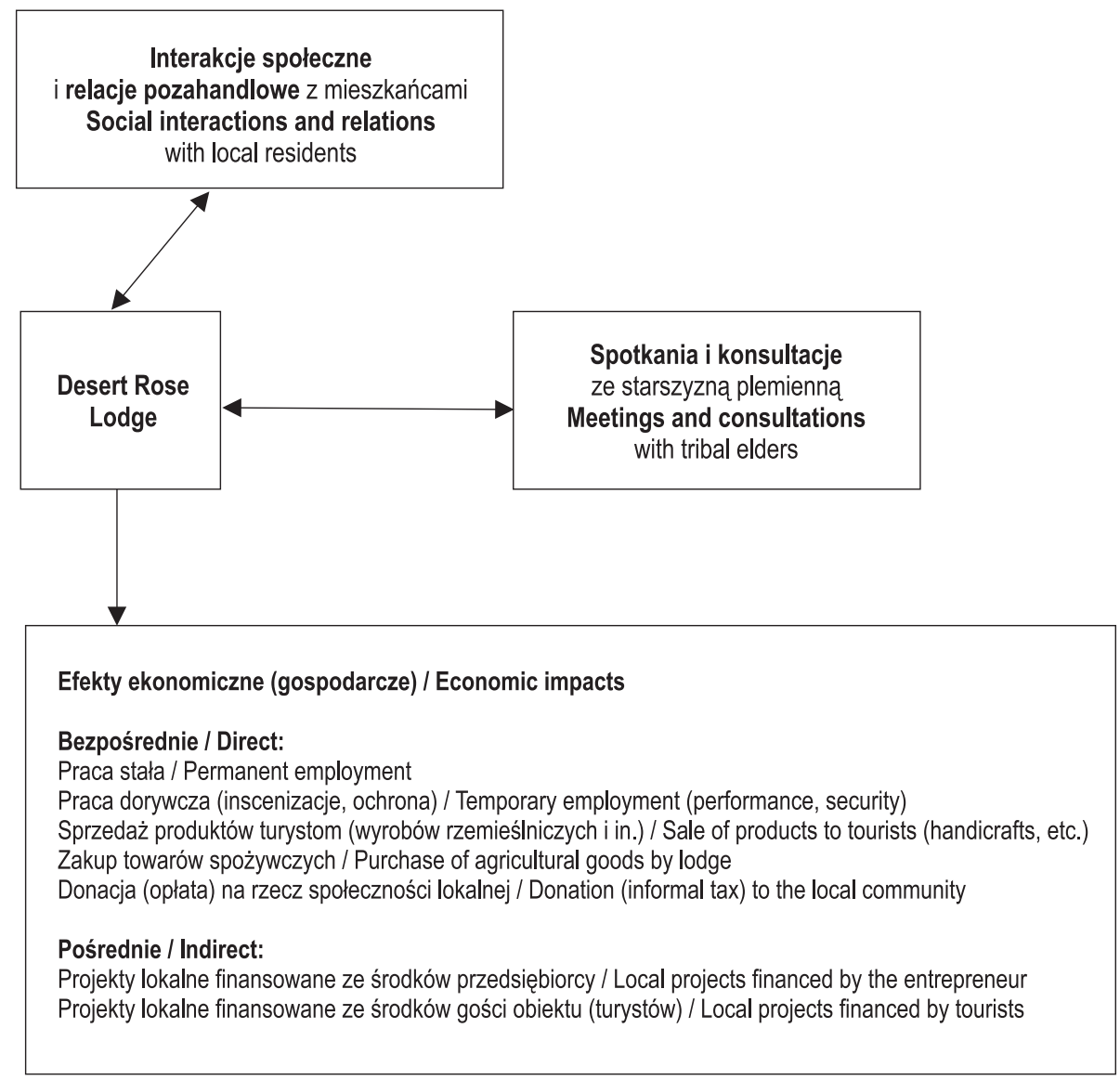

Ryc. 3. Model relacji Desert Rose Lodge ze społecznością lokalną

Fig. 3. Model of the Desert Rose Lodge relationship with the local community

\section{Konsultacje ze społecznością lokalną}

Budowanie relacji z miejscową społecznością odbywa się w formie cyklicznych spotkań ze starszyzną, które zazwyczaj mają miejsce w wyznaczonej do tego celu przestrzeni na głównym placu wsi. W trakcie tych spotkań omawia się wszystkie istotne kwestie problemowe dotyczące wzajemnych relacji. Intencją przedsiębiorcy jest m.in. uświadomienie mieszkańcom wagi utrzymania porządku i czystości na terenie wioski, co jest niezwykle istotne z perspektywy postrzegania tego miejsca przez turystów. Odrębną kwestią jest potrzeba ochrony lokalnych 
wartości przyrodniczych, szczególnie endemicznego górskiego lasu cedrowego, który jest intensywnie i w sposób niekontrolowany eksploatowany przez mieszkańców (np. wypalanie pni drzew w celu pozyskania miodu, materiał budowlany). Zamiarem przedsiębiorcy jest także uświadomienie mieszkańcom, że ochrona przyrody i zachowanie jej różnorodności są niezbędne z punktu widzenia rozwoju turystyki, co z kolei ma znaczenie dla wielkości środków finansowych, które ta społeczność uzyskuje. W trakcie takich właśnie spotkań akceptację członków starszyzny uzyskiwały propozycje wymienionych wyżej projektów realizowanych przez Desert Rose Lodge na rzecz tejże community.

Serię spotkań ze starszyzną poświecono na przedyskutowanie propozycji przedsiębiorcy, aby w otoczeniu wsi ustanowić obszar ochronny conservancy (kategoria obszarowej formy ochronny przyrody ujęta w kenijskim prawodawstwie), zarządzany przez lokalną społeczność we współpracy z Desert Rose Ltd. Powołanie takiej formy ochronnej umożliwiłoby rozwój dzikiej fauny (m.in. antylopy, słonie, szakale, zebry Grevy'ego), która wcześniej została wyparta z tego terytorium przez rozprzestrzeniającą się gospodarkę pasterską. Obserwacja dzikiej zwierzyny stanowi rdzeń produktu turystyki safari w Kenii. Tego rodzaju wspólne przedsięwzięcia mogłoby przyciągnąć więcej gości, a tym samym stworzyć więcej miejsc pracy, np. dla: rangersów (pracownicy ochrony conservancy), przewodników terenowych, kobiecych grup zajmujących się animacją kulturową gości (tańce, odwiedzanie wiosek, nauka rzemiosła). Rozwiązanie takie potencjalnie otworzyłoby także inne możliwości rozwoju lokalnej społeczności (lepszy dostęp do opieki medycznej, edukacja, poprawa poziomu życia). Osiąganie porozumienia ze starszyzną Samburu w sprawach naruszających ustalony tradycją sposób ich gospodarowania (wypas bydła, korzystanie z zasobów lasu) jest jednak niezwykle trudne, spotyka się z oporem i niechęcią wobec proponowanych zmian. W takim procesie konsultacji uwidacznia się też wyraźny rozdźwięk między potrzebą podejmowania względnie szybkich decyzji biznesowych a zwyczajowo rozłożonym w czasie sposobem osiągania porozumień w społecznościach plemiennych.

Ostatnio, po kilku latach negocjacji, raw bardziej bur*liwych, raw mniej, prwedstawiciele

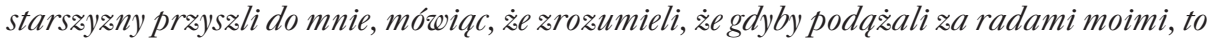
dzisiaj byliby w innym miejscu i proszq, aby wrócić do idei rejestracji rezerwatu. To bardzo

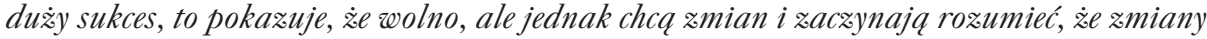
i rowwój sq dla nich dobre.

Jedna z wypowiedzi kadry zarządzającej pozwoliła na ogląd relacji między podmiotem biznesowym a społecznością lokalną w szerokiej perspektywie: ...aby uzyskać stabilizację biænesowq, stabilność dæiatań, bezpieczeństwo, harmonię funkcjonowania biænesu

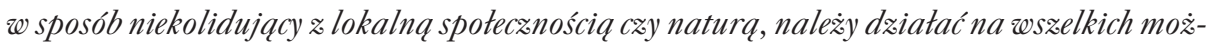
liwych ptaswczyznach tak, aby uzyskać obraz, ¿̇e biznes ma na wwadze wszystkie te elementy - 
i oczywiście ma, ale uświadomienie tego faktu wszystkim to nie lada wyzwanie. Wyłaniający się z tego stwierdzenia obraz sytuacji, w jakiej funkcjonuje Desert Rose Lodge, wyraźnie wskazuje, że podmiot zarządzający tym obiektem działa w środowisku lokalnym - przyrodniczym i społecznym - w co najmniej dwóch relacjach o wyraźnie siłowym charakterze. W obu przypadkach siły te działają dwukierunkowo (przeciwstawnie) i dla podmiotu biznesowego mają deterministyczny charakter. Jedna z nich dotyczy natury, a druga reprezentacji społeczności lokalnej, którą stanowi starszyzna plemienna. $Z$ przytoczonej wypowiedzi wynika, że strategia działania przedsiębiorcy w obu relacjach nie dąży do dominacji, lecz osiągania równowagi.

\section{Uwagi końcowe}

Omówione wyżej kwestie rzucają światło na sytuację rozwojową oraz sposób funkcjonowania wysoce specjalistycznego obiektu noclegowego położonego na peryferyjnym obszarze północnej Kenii w szczególnym kontekście uwarunkowań kulturowych. Przykład Desert Rose Lodge ukazuje sferę relacji - ekonomicznych i społecznych, jakie zawiązują się pomiędzy przedsiębiorcą turystycznym a rdzenną ludnością plemienną w procesie budowania łańcucha wartości i dostarczania go wymagającemu odbiorcy (turyście) w turystyce safari. Co istotne z poznawczego punktu widzenia, przedstawione studium przypadku uwypukla pewien szczególny sposób funkcjonowania turystycznego obiektu noclegowego w lokalnym środowisku geograficznym. Owa wyjątkowość wynika ze współistnienia podmiotu turystycznego i miejscowej społeczności plemiennej w przestrzennej bliskości oraz semi-izolacji od wpływów świata zewnętrznego. W efekcie pomiędzy Desert Rose Lodge a mieszkańcami pobliskiej wsi doszło do zawiązania się w czasie wielowątkowego układu relacji, które ukształtowały symbiotyczny charakter ich koegzystencji. Taki układ funkcjonalny nie został jedynie ,wymuszony” okolicznościami położenia obiektu turystycznego i obiektywnie istniejącym brakiem alternatyw w pozyskiwaniu zasobów ludzkich do pracy. W świetle przytoczonych wypowiedzi można postawić tezę, że w znacznej mierze jest on rezultatem aktywności tego podmiotu turystycznego i decyzji jego kadry zarządzającej, która - tworząc środowisko rozwoju własnego produktu - uznała za stosowne zaangażować się w życie lokalnej społeczności.

$Z$ procesu dostarczania wartości turystom obie strony nie tylko czerpią pożytek, ale w tym procesie współuczestniczą, wzajemnie się potrzebując. Sfera korzyści ekonomicznych, a za ich sprawą także społecznych, która z rozwoju turystyki się wykształciła, dla miejscowej ludności nie jest zamknięta i może zostać poszerzona za sprawą wzrostu liczby przyjazdów i wzbogacenia oferty produktowej Desert Rose Lodge. Co istotne, korzyści, których ta społeczność jest beneficjentem za sprawą działalności biznesowej, nie są przez przedsiębiorcę warunkowo reglamentowane 
i nie ograniczają się do oferowania pracy w odciętym od wpływów i pozbawionym relacji z otoczeniem obiekcie turystycznym, jak ma to miejsce w wielu innych rozwijających się regionach świata.

Opisany przykład Desert Rose Lodge w szczegółowy sposób ukazuje wielkość i kierunki przepływów środków finansowych z wydatków turystycznych do lokalnej społeczności. W jaki sposób natomiast przebiega dystrybucja i podział tychże korzyści wewnątrz grupy plemiennej Samburu, jest już kwestią odrębną i trudną do szczegółowego ustalenia. Podmiot biznesowy wchodzi z przedstawicielami miejscowej ludności także w różnorakie relacje o charakterze pozahandlowym (np. pomoc medyczna, pomoc w przemieszczaniu się, transport towarów). Spektrum i wielość interakcji sprawia, że w świadomości lokalnej społeczności Desert Rose Lodge stanowi trwały i nieodłączny element jej codzienności. Wzajemna bliskość przestrzenna sprawia więc, że w środowisku miejscowej ludności aktywność Desert Rose Lodge jest nie tylko łatwo dostrzegalna, ale także szybko odczuwalne są wszelkie korzyści z niej płynące.

Rozwój i sprawność działania Desert Rose Lodge warunkuje zrozumienie mechanizmów kulturowych determinujących życie plemiennej społeczności Samburu, a także dysponowanie określonymi ,atrybutami”, nie tylko ekonomicznymi, w kontaktach z jej miejscową grupą. Podmiot zarządzający obiektem musi wykazywać się zdolnością argumentacji i umiejętnością przekonywania starszyzny plemiennej do proponowanych przez siebie rozwiązań. Dotyczy to także sposobu wyjaśniania zmian tradycyjnych ról społecznych wzbudzanych w toku działalności stricte biznesowej (usługowej), np. w odniesieniu do pozycji kobiet, w tym uznania ich aktywności zarobkowej i decyzyjności w sferze zawodowej. W dyskusji przedstawicieli odległych względem siebie kultur ocena skuteczności przedstawionej argumentacji nigdy nie jest jednoznaczna. Niezwykle trudno odpowiedzieć na pytanie: czy do zainicjowania zmian w sposobie myślenia i kulturowo uwarunkowanych postawach właściwych dla społeczności pasterskiej wystarczy zaszczepienie przekonania wśród niektórych jej członków, że to właśnie praca zarobkowa w usługach daje korzyści, skoro przez całe pokolenia podstawową i nadrzędną wartością tej ludności było posiadanie bydła i jego ochrona.

W toku częstych spotkań przedsiębiorcy ze starszyzną zachodzi nie tylko proces uczenia się obu stron, ale też stopniowo dokonuje się rozwój lokalnej społeczności i jej aktywizacja. W kontekście zamierzeń podmiotu biznesowego odnośnie do powołania conservancy można stwierdzić, że miejscowa społeczność plemienna poprzez swoją reprezentację stała się de facto stroną w procesie planowania rozwoju turystyki na terytorium, które zamieszkuje. Wysunięcie takiej propozycji oznacza dla podmiotu biznesowego wejście na ścieżkę jeszcze głębszej współpracy ze starszyzną i przeniesienie jej na inny poziom organizacji. Z punktu widzenia społeczności plemiennej rodzi się natomiast pytanie: na ile jest ona przygotowana do podejmowania tak 
strategicznych decyzji i na ile jest skłonna zgodzić się na wprowadzanie rozwiązań, które mogą naruszać ustalony tradycją porządek? Problematyka, w jaki sposób postrzegane przez lokalną społeczność Samburu różnice kulturowe w jej zetknięciu ze „Światem” turystów i biznesu turystycznego determinują jej proces decyzyjny i dokonywane przez nią wybory, jest niezwykle istotna z perspektywy szerszej oceny możliwości jej włączania w sferę korzyści implikowanych rozwojem turystyki. Wyznacza ona pole niezwykle interesujących dociekań, lecz, jak się zdaje, trudnych do ustalenia z uwagi na wysoce hermetyczny charakter tejże społeczności, o czym autorzy niniejszego opracowania niejednokrotnie mogli się przekonać.

W kontekście wielokrotnie przytaczanych w literaturze przedmiotu przykładów, kiedy rozwój sektora przedsiębiorstw turystycznych doprowadzał do sytuacji jego dominacji i uzależnienia od siebie lokalnej sfery społeczno-gospodarczej, przypadek Desert Rose Lodge wskazuje na istnienie zjawiska o cechach w istocie przeciwstawnych. Funkcjonowanie tego obiektu ujawnia nieopisaną dotąd w literaturze naukowej sytuację rozwojową, którą z punktu widzenia turystycznego podmiotu biznesowego można określić jako „zależność odwrotną”. Opisywany podmiot gospodarczy nie może w pełni swobodnie zarządzać zasobami ludzkimi z uwagi na wspomniany wcześniej jej lokalny niedobór, nie może też zgodnie z potrzebami eksploatować zasobów przyrody i kształtować użytkowanej przez siebie przestrzeni, a także jest zmuszony do nieustannego podtrzymywania przekonania wśród przedstawicieli starszyzny plemiennej o etycznym charakterze własnych intencji względem tejże społeczności. Bez przeszkód można sobie wyobrazić sytuację, w której ewentualne wejście przedsiębiorcy na ścieżkę konfliktu z interesem lokalnej społeczności spowoduje, że starszyzna plemienna na mocy prawa zwyczajowego usankcjonuje potencjalnym wykluczeniem ze społeczności pracowników tego obiektu turystycznego. W opisanym przypadku dochodzi więc do „ścierania się” ekonomicznej siły pieniądza i kulturowo warunkowanej siły dominacji starszyzny plemiennej dysponującej tak potężnym narzędziem sprawowania władzy we własnym środowisku jak ,,przekleństwo" (ostracyzm). Równowaga w relacji sił pomiędzy stronami - przedsiębiorcą a starszyzną plemienną - utrzymuje się za sprawą wymiany świadczeń. Po stronie podmiotu biznesowego mają one charakter przede wszystkim ekonomiczny, po drugiej zaś wydają się wynikać z przyzwolenia starszyzny na obecność Desert Rose Lodge na ich „ziemi” (terytorium) oraz przekonania, że wartość świadczeń dostarczana przez przedsiębiorcę jest adekwatna do „kosztów” zmian kulturowych, które ich zdaniem miejscowa społeczność ponosi.

Autorzy pragną złożyć serdeczne podziękowania wszystkim osobom, które zgodziły się wziąć udział w badaniu, udzielić informacji i podzielić się własnymi opiniami. Szczególne podziękowania kierujemy do Zarządu firmy Desert Rose Ltd z Nairobi, bez którego zgody i pomocy badania te nie mogłyby zostać przeprowadzone. 


\section{Literatura}

Burns P., Novelli M. (red.), 2008, Tourism development: Growth, myths, and inequalities, CABI International, Wallingford.

Cole S., Morgan N. (red.), 2010, Tourism and inequality: Problems and prospects, CABI, Wallingford.

Higgins-Desbiolles F., 2018, The potential for justice through tourism, Via Tourism Review, Questions conceptuelles dans le champ du tourisme, 13, DOI:10.4000/viatourism.2469.

Higgins-Desbiolles F., 2008, Justice tourism: A pathway to alternative globalisation, Journal of Sustainable Tourism, 16 (3), 345-364.

Kahindi O., 2001, Cultural perceptions of elephants by the Samburu people in northern Kenya, University of Strathclyde, Glasgow.

Kowalczyk A. (red.), 2010, Turystyka «równoważona, Wydawnictwo Naukowe PWN, Warszawa. Kurek W. (red.), 2007, Turystyka, Wydawnictwo Naukowe PWN, Warszawa.

Mika M., 2014, Zato:̇enia i determinanty podtrzymywalności lokalnego rozwoju turystyki, Instytut Geografii i Gospodarki Przestrzennej UJ, Kraków.

Mika M., Zawilińska B., Pawlusiński R., 2015, Park narodowy a gospodarka lokalna. Model relacji ekonomicznych na przykładzie Babiogórskiego Parku Narodowego, Instytut Geografii i Gospodarki Przestrzennej UJ, Kraków.

Nash D., 1989, Tourism as a form of imperialism, [w:] V.L. Smith (red.), Hosts and guests: The anthropology of tourism, Blackwell, Oxford, 33-48.

Niezgoda A., 2006, Obszar recepcji turystycznej w warunkach rozwoju zrównoważonego, Prace Habilitacyjne, 24, Wydawnictwo Akademii Ekonomicznej w Poznaniu, Poznań.

Novelli M., 2015, Tourism and development in Sub-Saharan Africa. Current issues and local realities, Routledge, London.

Ole Sena S., Ssennyonga J.W., 1986, The Samburu people: Language and literature, Government of Kenya, University of Nairobi.

Pritchard A., Morgan N., Ateljevic I., 2011, Hopeful tourism: A transformative approach, Annals of Tourism Research, 38 (3), 941-963.

Simonse S., Kurimoto E., 1998, Conflict, age and power in north East Africa: Age systems in transition, London: James Currey, Dar es Salaam: Mkuki na Nyota, Nairobi, East African Education Publishers. Athens, Ohio University Press.

Simpson G.L., Waweru P., 2012, Becoming Samburu: The ethnogenesis of a pastoral people in nineteenth-century Northern Kenya, The Journal of the Middle East and Africa, 3 (2), 175-197.

Sommer G., Vossen R., 1993, Dialects, sectiolects, or simply lects? The Maa language in time perspective, [w:] T. Spear, R. Waller (red.), Being Maasai - ethnicity andidentity in East Africa, London: James Currey, Dar es Salaam: Mkuki na Nyota, Nairobi East African Education Publishers. Athens: OhioUniversity Press, 25-37.

Spencer P., 2004, The Samburu. Anthropology and ethnography, Routledge, Oxon. 
Straight B., 2005, Cutting time: Beads, sex, and songs in the making of Samburu memory, [w:] W. James, D. Mills (red.), The qualities of time: Temporal dimensions of social form and human experience, ASA Monograph Series, 41, Wendy James and David Mills, Berg Publishers, London, 269-277.

UNWTO, 2019, Recommendations on sustainable development of indigenous tourism, UNWTO World Tourism Organization, Madrid, DOI: 10.18111/9789284421299.

Zasoby - www.e-unwto.org.

Mirostaw Mika, Tomasz Kepski

Uniwersytet Jagiellonski

Wydziat Geografii i Geologii

Instytut Geografii i Gospodarki Przestræennej

ul. Gronostajowa 7, 30-387 Kraków

miroslaw.mika@uj.edu.pl

tomasz.kepski@gmail.com 